\title{
Elevated Tumor Necrosis Factor in Serum Is Associated with Increased Retinal Ischemia in Proliferative Eales' Disease
}

\author{
Sandeep Saxena ${ }^{a}$ Vinay K. Khanna ${ }^{b}$ Aditya B. Pant ${ }^{b}$ Carsten H. Meyer \\ Vijay K. Singh ${ }^{d}$ \\ a Department of Ophthalmology, CSM Medical University, and ${ }^{b}$ Industrial Toxicology Research Center, Lucknow, \\ India; ' Department of Ophthalmology, University of Bonn, Bonn, Germany; ${ }^{\mathrm{d}}$ Radiation Counter Measures Program, \\ Armed Forces Radiobiology Research Institute, Bethesda, Md., USA
}

\section{Key Words}

Eales' disease $\cdot$ Tumor necrosis factor $\cdot$ Cytokine $\cdot$

Neovascularization $\cdot$ Cell death signaling $\cdot$ Retina

\begin{abstract}
Objective: Tumor necrosis factor (TNF) was evaluated in the serum of patients with proliferative stage of Eales' disease to study its relation with the area of retinal capillary non-perfusion (ischemic retina). Methods: Quantification of the levels of TNF was done using sandwich ELISA in 52 cases with proliferative Eales' disease and in 32 healthy controls. Seven $50^{\circ}$ photographs of different fields of the fundus were taken on fluorescein angiography. The area of retinal capillary nonperfusion denoting retinal cell death was assessed in terms of optic disc areas. Results: TNF levels were found to be significantly increased in the proliferative stage of the disease (mean $23.64 \pm 3.7 \mathrm{pg} / \mathrm{ml}$ ) as compared to controls (mean $12.49 \pm 2.9 \mathrm{pg} / \mathrm{ml} ; \mathrm{p}<0.001)$. Higher levels of TNF were found to be associated with an increased area of retinal capillary non-perfusion on fluorescein angiography. TNF levels of $20-31 \mathrm{pg} / \mathrm{ml}$ were observed in cases with neovascularization at the disc $(n=33)$ as compared to $17-21 \mathrm{pg} / \mathrm{ml}$ in cases
\end{abstract}

with neovascularization elsewhere $(n=19)$. Conclusions: An increased level of TNF is associated with an increased area of the ischemic retina. It is hypothesized that retinal cell death signaling in proliferative Eales' disease is related to an increased TNF level.

Copyright $\odot 2011$ S. Karger AG, Basel

\section{Introduction}

Eales' disease is an idiopathic obliterative vasculopathy that primarily affects the peripheral retina of young adult males [1]. Retinal changes are characterized by periphlebitis, peripheral non-perfusion and neovascularization $[2,3]$. The natural history of Eales' disease is quite variable, with temporary or even permanent remission in some cases and relentless progression to blindness in others. Visual loss is characteristically caused by recurrent vitreous hemorrhage and their sequelae [4]. Autoimmunity to retinal antigens has been found to play an important role in the etiopathogenesis of this disease. An extraneous agent results in the exposure of normally sequestered uveitopathogenic antigens of the immune system,

\section{KARGER}

Fax +41613061234 E-Mail karger@karger.ch www.karger.com
(C) 2011 S. Karger AG, Basel

$1015-2008 / 11 / 0785-0261 \$ 38.00 / 0$

Accessible online at:

www.karger.com/pat
Prof. Sandeep Saxena, MS

Department of Ophthalmology

CSM Medical University

Lucknow 226003 (India)

Tel. +91941516 0528, E-Mail sandeepsaxena2020@yahoo.com 
leading to an immune response in the eye that initiates the disease process [5]. Resultant oxidative stress leads to retinal photoreceptor dysfunction as the retina is prone to oxidative stress because of its high content of polyunsaturated fatty acids [6].

Eales' disease is distinctively characterized both by stage of inflammation as well as by stage of proliferation [7]. Hypoxia-induced expression of vascular endothelial growth factor is an important aspect of a variety of complicated processes in intraocular neovascularization [8]. Chemokines have also been found to play a role in intraocular neovascularization [9]. A cascade of multiple angiogenic cytokines induced by oxidative damage, associated with tissue hypoxia, may interact to promote sustained retinal neovascularization [10].

Tumor necrosis factor (TNF) is a pleiotropic inflammatory cytokine. It is an acute-phase protein which initiates a cascade of cytokines and increases vascular permeability [11].

TNF is primarily produced as a 212 -amino-acidlong type II transmembrane protein arranged in stable homotrimers $[12,13]$. From this membrane-integrated form, the soluble homotrimeric cytokine (sTNF) is released via proteolytic cleavage by the metalloprotease TNF-converting enzyme [14]. Dysregulation and overproduction of TNF have been implicated in a variety of human diseases [15]. TNF-R1 (p55 receptor) and TNF-R2 (p75 receptor) are the 2 receptors which bind to TNF. Upon contact with their ligand, TNF receptors (TNFRs) form trimers. This binding causes a conformational change to occur in the receptor $[16,17]$. Activation of the mitogen-activated protein kinase pathways is involved in cell differentiation and proliferation, and is generally proapoptotic. Like all death domain-containing members of the TNFR superfamily, TNF-R1 is involved in cell death signaling [18]. The cytosolic domains of this receptor are unique in their ability to activate intracellular signals leading to apoptosis. The TNFR-associated factors are also involved in this process. The TNF-R1 cytosolic domains also recruit the family of intracellular proteins called 'TNFR-associated death domains'. Overexpression of TNFR-associated death domains results in cell death. An exhilarating aspect of the biology of TNF is its ability to both protect neurons as well as to initiate their selfdestruction [19].

Interleukin- 1 and TNF have a significant role to play in causation of retinal periphlebitis and neovascularization in Eales' disease [20]. Higher levels of TNF were observed in association with the increased severity of retinal periphlebitis [21]. High TNF- $\alpha$-expressing genotype of the host can influence the occurrence and severity of outcome of Eales' disease [22]. In the present study, we evaluated TNF in the serum of patients with proliferative Eales' disease and studied its association with the area of retinal capillary non-perfusion (ischemic retina) on fluorescein angiography.

\section{Patients and Methods}

The study group consisted of 52 consecutive patients with proliferative Eales' disease, classified according to the new staging system of Eales' disease [6] [proliferative stage (stage 3a) characterized by retinal/disc neovascularization], presenting in the retina clinic of a tertiary care center over a period of 18 months. All the patients were males. Thirty-two healthy controls, all males, presenting for refraction in the outpatient department were included. They were not on any medication and did not show tuberculin skin test reactivity. Informed consent was obtained from all patients and controls before their inclusion in the study. Systemic disorders such as tuberculosis, diabetes mellitus, sickle cell hemoglobinopathy, blood dyscrasias, sarcoidosis and collagen vascular diseases were ruled out after proper history examination and investigations (chest X-ray, fasting and postprandial blood sugar, sickle cell preparation, hemoglobin, hematocrit, total red and white blood cell count, differential count, erythrocyte sedimentation rate, serum angiotensin-converting enzyme, and antinuclear antibody), respectively. A complete ophthalmological assessment (including Snellen's visual acuity assessment, slit lamp biomicroscopy and indirect ophthalmoscopy) of the patient was done at baseline.

All the patients underwent fluorescein angiography. Seven $50^{\circ}$ photographs of different fields of the fundus were taken. Field 1 was centered on the optic disc, field 2 on the macula and field 3 temporal to the macula. Fields $4-7$ were centered tangential to the horizontal lines passing through the upper and lower poles of the disc and to a vertical line passing through its center. The area of retinal capillary non-perfusion (ischemic nonfunctional retina) was defined as the retinal area not perfused by the fluorescein dye. The area of capillary non-perfusion was assessed in terms of disc areas. Patients were eligible for this study if they (1) had not undergone laser photocoagulation, (2) had not received oral steroids within the last 3 months, (3) had not been on any immunosuppressive therapy, and (4) were non-smokers and non-alcoholics.

Elisa kits for quantification of the levels of serum TNF were purchased from eBioscience (San Diego, Calif., USA). Five milliliters of venous blood was drawn in a disposable syringe. Blood samples were processed for isolation of serum by centrifugation under sterile conditions. Serum samples were kept at $-80^{\circ} \mathrm{C}$ until used for the analysis. For the quantification of the levels of TNF in the serum samples of patients, sandwich ELISA was performed as per the protocol provided by the manufacturer.

Data were presented as the mean \pm SD. STATA 9.2 statistical software package (StataCorp, College Station, Tex., USA) was used to analyze the data. Two-tailed t test was used to test the level of significance between the 2 groups. Differences were considered significant if the $\mathrm{p}$ value was found to be $<0.05$. 


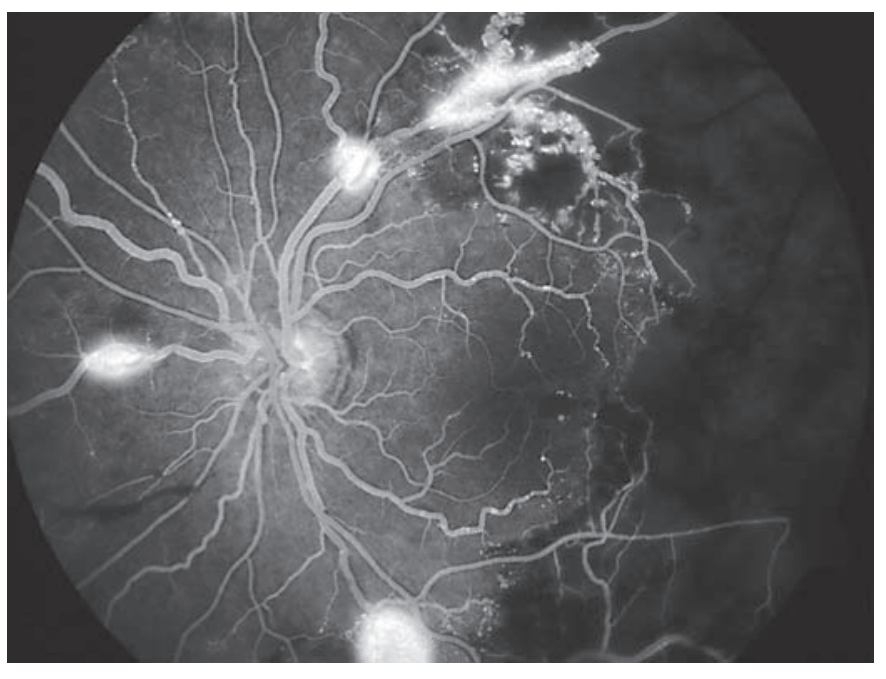

Fig. 1. Fluorescein angiography shows multiple NVE with capillary non-perfusion.

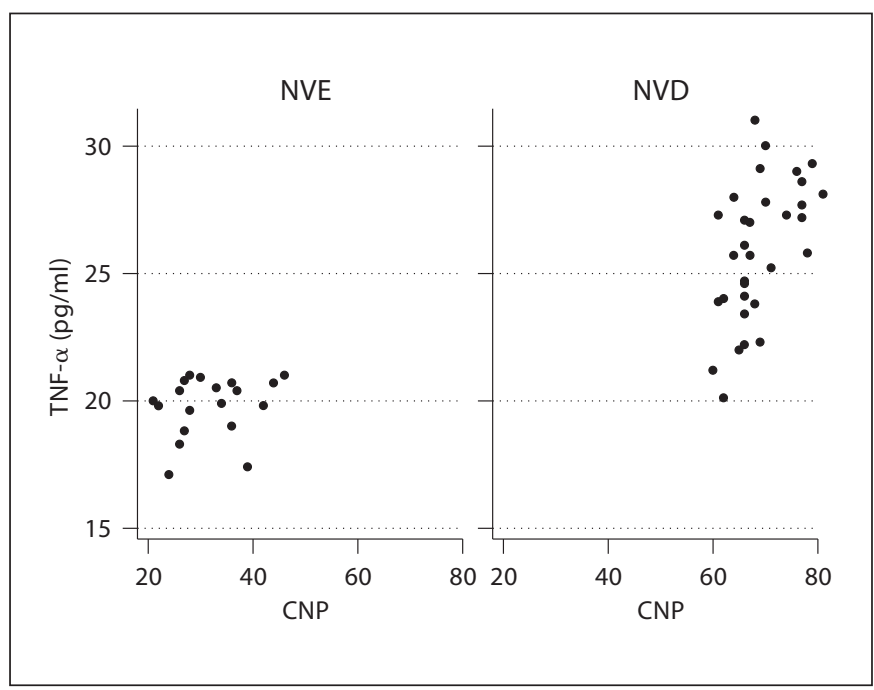

Fig. 3. Association between serum TNF levels and the area of retinal capillary non-perfusion (CNP) in cases of proliferative Eales' disease with NVE and NVD is shown as scatter plot.

\section{Results}

The mean age of the patients with proliferative Eales' disease was $28.1 \pm 3.9$ years (proliferative stage). The mean age of the controls was $30.6 \pm 2.1$ years. The patients and the controls did not differ in age $(\mathrm{p}>0.05)$. None of the patients or the controls had an undetectable

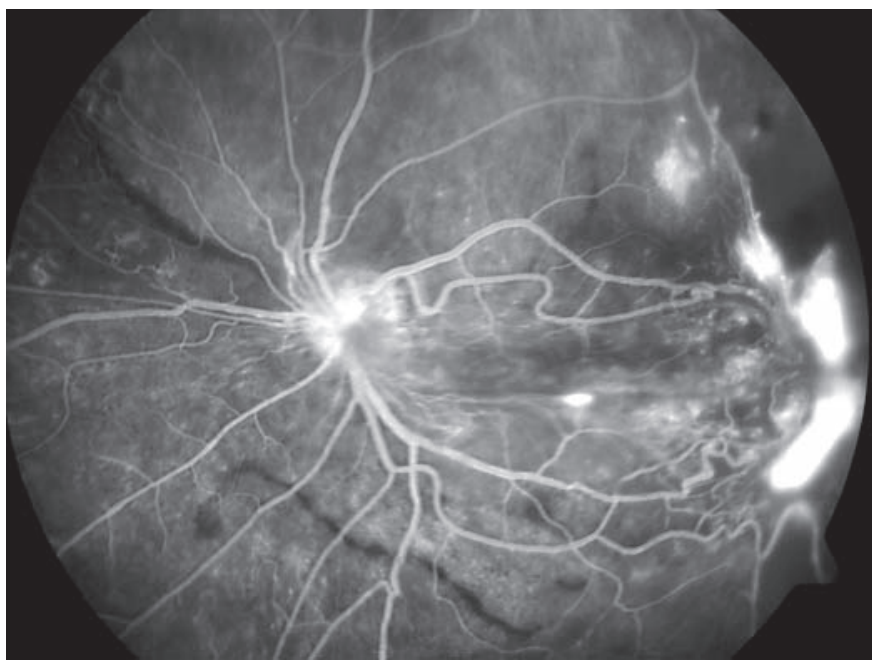

Fig. 2. Fluorescein angiography shows NVD and multiple NVE with capillary non-perfusion.

level of TNF, and we were able to detect TNF in all samples tested.

Mean TNF levels were $23.64 \pm 3.7$ and $12.49 \pm 2.9$ $\mathrm{pg} / \mathrm{ml}$ for cases and controls, respectively. TNF- $\alpha$ levels were found to be significantly increased in the serum samples of the cases with proliferative stage of Eales' disease as compared to controls $(\mathrm{p}<0.001)$. Neovascularization elsewhere (NVE; $\mathrm{n}=19$ ) and neovascularization on the disc (NVD; $\mathrm{n}=33$ ) were observed in cases with $>20$ disc areas and $>60$ disc areas of retinal capillary nonperfusion (ischemic non-functional retina), respectively (fig. 1,2). Comparatively higher levels of TNF were found to be associated with an increased area of retinal capillary non-perfusion. A TNF level of 20-31 pg/ml (mean 25.92 \pm 2.7 ) was observed in cases with NVD as compared to $18-21 \mathrm{pg} / \mathrm{ml}$ (mean $19.79 \pm 1.2$ ) in NVE. The association between serum TNF levels and the area of retinal capillary non-perfusion is shown in figure 3 .

\section{Discussion}

Our study has highlighted that an increased level of TNF is related to cell death signaling in the retina.

Significant TNF expression, in serum, was observed during the proliferative stage of Eales' disease. As the disease progressed from the NVE to the NVD stage, an associated increase in TNF level was observed. In the disease process, increased levels of TNF were found to be 
associated with an increased area of capillary non-perfusion. Hence, the TNF level was observed to increase with increased retinal cell death as denoted by the area of capillary non-perfusion. It may be hypothesized that increased TNF led to increased retinal cell death signaling.

The association of retinal capillary non-perfusion with angiogenesis (NVE and NVD) is well recognized in Eales' disease. More than 20 disc areas and 60 disc areas of the ischemic retina have been found to be associated with NVE and NVD, respectively [23, 24].

Our findings indicate that TNF- $\alpha$ may play a significant role in inducing cell death signaling during the proliferative stage of the disease. Intravitreal measurement of TNF- $\alpha$ was not possible due to ethical reasons. The serum TNF level has been found to correlate with the retinal level [25]. A biphasic elevation of TNF in the serum and an increase in the retina, both at the mRNA and the protein levels, within $24 \mathrm{~h}$, has been observed in an experimental model of central retinal artery occlusion which triggers retinal ischemia and a subsequent inflam- matory reaction [25]. TNF has been implicated as a mediator of apoptotic neuronal damage after ischemia. TNF has been found to play a largely deleterious role in ischemia-reperfusion injury in an in vivo model of retinal injury. Direct neutralization of this cytokine partially preserves the retinal function [26]. In an experimental mouse model of ischemic retinal neovascularization, TNF- $\alpha$ was found to participate in retinal neovascularization during postischemic inflammation through the induction of potent angiogenic factors in an autocrine or paracrine manner [27]. Patients with Eales' disease often express positive serology for tuberculosis. Differential serum cytokine levels are associated with cytokine gene polymorphisms in patients with active pulmonary tuberculosis [28]. However, none of our study subjects had tuberculosis.

Our data highlight that an elevated serum TNF level and thereby retinal TNF level [25] is significantly associated with cell death signaling causing retinal ischemia in proliferative Eales' disease.

\section{References}

1 Gieser SC, Murphy RP: Eales' disease; in Ryan SJ (ed): Retina Vol II. Medical Retina. St Louis, CV Mosby, 1994, pp 1503-1507.

$\checkmark 2$ Atmaca LS, Idil A, Gunduz K: Visualization of retinal vasculitis in Eales disease. Ocul Immunol Inflamm 1993;1:41-44.

-3 Bali T, Saxena S, Kumar D, Nath R: Response time and efficacy of oral methotrexate pulsed therapy in idiopathic retinal periphlebitis. Eur J Ophthalmol 2005; 15:374378.

4 Kumar D, Saxena RC, Saxena S: Vitreous haemorrhage in Eales' disease. Afro-Asian J Ophthalmol 1995;13:109-112.

-5 Saxena S, Rajasingh J, Biswas S, Kumar D, Shinohara T, Singh VK: Cellular response to retinal $\mathrm{S}$-antigen and interphotoreceptor retinoid binding protein fragments in patients with Eales' disease. Pathobiology 1999; 67:37-44.

- 6 Saxena S, Srivastava P, Kumar D, Khanna VK, Seth PK: Decreased platelet membrane fluidity in retinal periphlebitis in Eales' disease. Ocul Immunol Inflamm 2006;14:113116.

7 Saxena S, Kumar D: A new staging system for idiopathic retinal periphlebitis. Eur J Ophthalmol 2004;14:236-239.

8 Inomata $\mathrm{H}$, Ishibashi $\mathrm{T}$, Murata T, Iwasaki M, Tahara A, Hata K, et al: Intraocular neovascularization. Nippon Ganka Gakkai Zasshi 1997;101:90-96.
\$ Kawashima M, Shoji J, Kamura Y, Sato Y: Role of chemokines in the vitreous of proliferative diabetic retinopathy. Nippon Ganka Gakkai Zasshi 2005;109:596-602.

10 Armstrong D, Ueda T, Ueda T, et al: Lipid hydroperoxide stimulates retinal neovascularization in rabbit retina through expression of tumor necrosis factor-alpha, vascular endothelial growth factor and platelet-derived growth factor. Angiogenesis 1998;2: 93-104.

11 Dinarello CA: Proinflammatory cytokines. Chest 2000;118:503-508.

$>12$ Kriegler M, Perez C, DeFay K, Albert I, Lu SD: A novel form of TNF/cachectin is a cell surface cytotoxic transmembrane protein: ramifications for the complex physiology of TNF. Cell 1988;53:45-53.

13 Tang P, Hung MC, Klostergaard J: Human pro-tumor necrosis factor is a homotrimer. Biochemistry 1996;35:8216-8225.

14 Black RA, Rauch CT, Kozlosky CJ, Peschon JJ, Slack JL, Wolfson MF, et al: A metalloproteinase disintegrin that releases tumour-necrosis factor-alpha from cells. Nature 1997; 385:729-733.
15 Locksley RM, Killeen N, Lenardo MJ: The TNF and TNF receptor superfamilies: integrating mammalian biology. Cell 2001;104: 487-501.

16 Wajant H, Pfizenmaier K, Scheurich P: Tumor necrosis factor signaling. Cell Death Differ 2003; 10:45-65.

17 Chen G, Goeddel DV: TNF-R1 signaling: a beautiful pathway. Science 2002;296:16341635 .

18 Gaur U, Aggarwal BB: Regulation of proliferation, survival and apoptosis by members of the TNF superfamily. Biochem Pharmacol 2003;66:1403-1408.

$\checkmark 19$ Hunter CA, Timans J, Pisacane P, Menon S, Cai G, Walker W, et al: Comparison of the effects of interleukin-1 alpha, interleukin-1 beta and interferon-gamma inducing factor on the production of interferon-gamma by natural killer. Eur J Immunol 1997;27:2787-2792.

-20 Saxena S, Pant AB, Khanna VK, Singh K, Kumar D, Singh VK: Interleukin-1 and tumor necrosis factor-alpha: novel targets for immunotherapy in Eales' disease. Ocul Immunol Inflamm 2009; 17:201-206.

-21 Saxena S, Pant AB, Khanna VK, Singh K, Shukla RK, Meyer CH, Singh VK: Tumor necrosis factor- $\alpha$-mediated severity of idiopathic retinal periphlebitis in young adults (Eales' disease): implication for anti-TNF- $\alpha$ therapy. J Ocul Dis Biol Inform 2010;3:3538. 
-22 Sen A, Paine SK, Chowdhury IH, Mondal LK, Mukherjee A, Biswas A, et al: Association of interferon-gamma, interleukin-10, and tumor necrosis factor-alpha gene polymorphisms with occurrence and severity of Eales' disease. Invest Ophthalmol Vis Sci 2011;52:171-178.

-23 Saxena S, Kumar D, Maitreya A, Srivastava P, Khanna VK, Nath R, et al: Retinal neovascularization in Eales' disease. Ann Ophthalmol 2003;35:25-27.
24 Saxena S, Kumar D: Topographic distribution of retinal neovascularization in Eales' disease. Ann Ophthalmol 2005;37:273-275.

-25 Kramer M, Dadon S, Hasanreisoglu M, Monselise Y, Avraham BR, Feldman A, Eldar I, Weinberger D, Goldenberg-Cohen N: Proinflammatory cytokines in a mouse model of central retinal artery occlusion. Mol Vis 2009; 15:885-894.

26 Berger S, Savitz SI, Nijhawan S, Singh M, David D, Rosenbaum PS, Rosenbaum DM: Deleterious role of TNF-alpha in retinal ischemia-reperfusion injury. Invest Ophthalmol Vis Sci 2008;49:3605-3610.
27 Yoshida S, Yoshida A, Ishibashi T: Induction of IL-8, MCP-1, and bFGF by TNF-alpha in retinal glial cells: implications for retinal neovascularization during post-ischemic inflammation. Graefes Arch Clin Exp Ophthalmol 2004;242:409-413.

28 Abhimanyu, Mangangcha IR, Jha P, Arora $\mathrm{K}$, Mukerji M, Banavaliker JN, Indian Genome Variation Consortium, et al: Differential serum cytokine levels are associated with cytokine gene polymorphisms in north Indians with active pulmonary tuberculosis. Infect Genet Evol 2011;11:1015-1022. 